\title{
PROSES PELAYANAN SOSIAL BAGI WARIA MANTAN PEKERJA SEKS KOMERSIAL DI YAYASAN SRIKANDI SEJATI JAKARTA TIMUR
}

\author{
Oleh: \\ Chenia Ilma Kirana, Hery Wibowo, \& Santoso Tri Raharjo \\ Email: \\ cheniaakirana@gmail.com
}

\begin{abstract}
ABSTRAK
Wanita-pria, atau yang lebih dikenal dengan waria adalah salah satu kelompok minoritas yang keberadaannya sering dipinggirkan oleh masyarakat. Pandangan buruk dari masyarakat mengenai kaum yang seolah-olah 'tidak bersyukur' dengan kodratnya ini membuat waria sulit untuk mendapatkan pekerjaan secara layak. Oleh karena itu, banyak dari mereka yang terpaksa menjadi pekerja seks komersial guna menyambung hidup. Tak hanya itu, persoalan menjadi waria adalah sulitnya mereka untuk memenuhi keberfungsian sosialnya karena dianggap tak lagi sesuai dengan nilai dan norma yang dianut masyarakat kebanyakan. Bagaimana agar para waria yang bekerja menjadi pekerja seks komersial ini sadar dan mau untuk keluar dari pekerjaan tersebut adalah dengan memberikan pelayanan sosial. Pelayanan sosial yang nantinya membuat mereka menyadari bahwa hidup waria layak dijalani dan bisa terus percaya diri ketika bermasyarakat.
\end{abstract}

Kata kunci: waria, pekerja seks komersial, pelayanan sosial, keberfungsian sosial

\section{PENDAHULUAN}

Waria (wanita-pria) atau wadam (wanitaadam) adalah kaum ketiga yang hadir di tengah masyarakat Indonesia setelah laki-laki dan perempuan. Waria adalah individu berciri fisik berkelamin pria, tetapi cenderung menampilkan diri sebagai wanita, baik dalam penampilan maupun perilaku. Waria dalam konteks psikologis termasuk sebagai penderita transeksualisme, yakni seseorang yang secara jasmani jenis kelaminnya jelas dan sempurna, namun secara psikis cenderung untuk menampilkan diri sebagai lawan jenis (Heuken, 1989:148)

Dalam masyarakat Indonesia, waria dianggap sebuah penyimpangan seksual karena jenis seks yang diakui secara sah oleh masyarakat adalah laki-laki dan perempuan. Waria dipandang sebagai individu yang patologis secara sosial karena penyimpangan seksual yang ada dalam diri seorang waria ternyata telah melahirkan suatu bentuk penyimpangan sosial meskipun hukum menyadari bahwa perbuatan itu di luar keinginan pelaku dan merupakan penyakit (Soedjono, 1982: 147)

Perkembangan eksistensi waria di Indonesia pun kini tidak bisa dipungkiri. Pada tahun 2010, Direktorat Rehabilitasi Sosial Tuna Sosial menyebutkan bahwa terdapat 31.179 waria di Indonesia. Jumlah ini menurun dari data yang disebutkan oleh Kementerian Kesehatan RI pada tahun 2006 yang memperkirakan bahwa ada 20.960 hingga 35.300 waria di Indonesia dan 3.500 diantaranya menetap di DKI Jakarta. Sumber 
data lain menyebutkan, jumlah waria di DKI Jakarta yang tercatat di Yayasan Srikandi Sejati hingga November 2010 berjumlah 2960 orang. Jumlah tersebut tentu bukan jumlah yang sedikit dan bisa saja meningkat setiap tahunnya.

Banyaknya jumlah waria tidak sertamerta membuat masyarakat menganggap kaum waria sebagai kaum yang 'wajar'. Dalam kenyataannya, masih banyak perlakuan buruk yang menimpa para waria mulai dari adanya penolakan di dalam keluarga, kurang diterima atau bahkan tidak diterima secara sosial, dianggap sebagai lelucon, hingga kekerasan baik verbal maupun non verbal (Dep. Sos RI, 2008)

Waria banyak menghadapi masalah dari dalam maupun dari luar sebagai konsekuensi pemilihan hidup mereka (Koeswinarno, 2004: 28). Keterasingan yang dialami oleh kaum waria juga membuat mereka senantiasa mengalami hambatan dalam melakukan pergaulan atau pun memilih pekerjaan (Koeswinarno, 2004: 9).

\section{PEMBAHASAN}

Surahman (2007) mengungkapkan waria ditolak untuk menjadi pegawai negeri, karyawan di kantor-kantor swasta, atau berbagai profesi lainnya, bahkan waria juga mengalami penolakan dan permasalahan dalam mengurus KTP. Kondisi yang dihadapi waria tersebut menyebabkan waria sulit mendapatkan pekerjaan, padahal mereka juga sesama warga negara yang berhak dianggap setara ketika memilih pekerjaan untuk melanjutkan kehidupan.

Sampai saat ini keberadaan waria khususnya di Indonesia belum diakui, dan masih diasingkan dari ruang sosial, budaya, maupun politik dimana diskriminasi terjadi pada komunitas ini karena adanya stigma negatif dari masyarakat terhadap mereka. Perlakuan terhadap waria yang diskriminatif tersebut tanpa disadari menjadikan mereka kelompok masyarakat yang termarjinalkan. Termasuk dalam hal lapangan pekerjaan, akibatnya kehidupan mereka lebih terbatas sehingga membuat mereka sulit bergerak, atau dengan kata lain ruang gerak mereka menjadi sempit, bidang pekerjaan yang dijalani sangat terbatas.

Lapangan kerja yang bersifat formal sulit untuk dimasuki oleh kaum waria, karena pada saat mengisi formulir pendaftaran maupun surat lamaran pasti tercantum dua pilihan jenis kelamin yaitu laki-laki dan perempuan, tetapi tidak ada jenis kelamin waria. Dunia kerja yang semakin tidak bersahabat ini membuat mereka semakin kepepet dan akhirnya memilih bekerja di sektor informal (Etty Padmiati, 2008: 5)

Sektor-sektor informal tersebut berupa menjadi pegawai salon, pengamen, bahkan menjadi Pekerja Seks Komersial (PSK). Berdasarkan data dari Forum Komunikasi Waria DKI Jakarta pada tahun 2007, persentase waria yang bekerja sebagai PSK adalah sebesar $60 \%$, pengamen $10 \%$, pekerja salon dan lain-lain sebesar 30\%. Banyaknya waria yang menjadi pekerja seks komersial dikarenakan kebutuhan yang mendesak sedangkan tidak ada lagi kesempatan pekerjaan di bidang formal.

Demikian pula menurut Yanti Saraswati yang dikutip oleh Zunly Nadia (2005:2), bahwa banyaknya waria yang melacurkan diri disebabkan oleh pribadi mereka yang tidak mempunyai keahlian khusus, akhirnya prostitusi menjadi alternatif untuk mempertahankan hidupnya.

Kembali lagi kepada perlakuan diskriminatif dari masyarakat tersebut, membuat waria memiliki konsep diri yang rendah sehingga sulit bermasyarakat dan tidak mengetahui potensi apa yang mereka miliki. Pada akhirnya, menjadi pekerja seks komersial atau melacur identik dengan kehidupan waria.

Jumlah waria yang bekerja sebagai pekerja seks cukup tinggi, kondisi ini turut mendukung tingginya angka penderita Human Immuno Deviciency Virus (HIV) - Acquired Immuno Deviciency Syndrome (AIDS) di Indonesia khususnya di wilayah DKI Jakarta. 
Populasi yang berisiko tinggi terhadap penularan HIV/AIDS adalah waria. Kerentanan populasi ini terutama disebabkan oleh perilaku seksual berisiko seperti seks anal dan kecenderungan berganti - ganti pasangan. Saat ini, DKI Jakarta menempati prevalensi tertinggi Infeksi Menular Seksual (IMS) anus dan rektum serta HIV pada kalangan waria di Indonesia.

Surveilans Terpadu Biologis Perilaku (STBP) pada kelompok beresiko tinggi di Indonesia (2007) mengungkapkan data prevalensi HIV pada waria di wilayah DKI Jakarta mengalami peningkatan dari $0,3 \%$ pada tahun 1995 menjadi 34\% di tahun 2007. Prevalensi IMS di anus dan rektum pada waria di Jakarta 42\%. IMS diketahui dapat meningkatkan kerentanan seseorang terhadap infeksi HIV 1-9 kali lipat.

Masih dari data STBP 2007 bahwa sebagian besar waria ( $>80 \%$ waria di 4 kota dan $72 \%$ di 1 kota) menjual seks kepada pelanggan pria. Di samping itu $40-50 \%$ waria juga berhubungan seks dengan pria pasangan tetap yang disebut dengan "suami". STBP di tahun 2011 juga menyebutkan bahwa prevalensi HIV pada waria pada tahun 2011 terus meningkat hingga $23,2 \%$. Tingginya tingkat prevalensi HIV juga disebabkan oleh rendahnya kesadaran waria untuk menggunakan kondom ketika berhubungan seksual. Ini juga disebabkan oleh rendahnya pengetahuan kaum waria terhadap kesehatan.

Rentannya penularan HIV terhadap waria terutama yang dilakukan oleh pekerja seks komersial pada akhirnya akan membahayakan waria itu sendiri juga para konsumennya. Hal ini memerlukan penanganan yang lebih serius guna mencegah peningkatan jumlah HIV/AIDS di Indonesia yang dapat merusak generasi selanjutnya.

Waria yang bekerja sebagai pekerja seks komersial termasuk ke dalam salah satu Penyandang Masalah Kesejahteraan Sosial (PMKS) mengingat pekerjaan tersebut menimbulkan dampak negatif bagi masyarakat dan bagi waria itu sendiri. Selain itu, stigma negatif dan perlakuan diskriminatif dari masyarakat menyebabkan mereka sulit untuk mencapai keberfungsian sosialnya.

\section{SIMPULAN:}

Salah satu hal yang bisa dilakukan untuk meningkatkan keberfungsian sosial serta mengurangi tingkat HIV/AIDS adalah dengan menyadarkan waria bahwa menjadi pekerja seks komersial bukanlah hal yang patut dilakukan untuk melanjutkan kehidupan. Bagaimana cara menyadarkan waria adalah dengan memberikan mereka pelayanan sosial. Pelayanan sosial yang menurut Alfred J. Khan sebagai sebuah pemberian pelayanan kesehatan, pendidikan, dan kesejahteraan untuk memperlancar kemampuan individu dalam memenuhi kebutuhan dasarnya. Pemberian pelayanan sosial yang diharapkan mampu membuat waria menyadari bahwa menjadi pekerja seks komersial akan merugikan lingkungan dan diri sendiri. Pemberian pelayanan sosial yang membantu waria memahami potensi apa yang mereka miliki serta dapat mengembangkannya sehingga membuat hidup mereka menjadi lebih baik dan bisa diakui di masyarakat.

Adapun fungsi pelayanan sosial yang juga menurut Alfred J. Khan adalah pertama, untuk tujuan sosialisasi dan pengembangan, pelayanan sosial ini diadakan untuk melindungi, mengadakan perubahan atau penyempurnaan kegiatan-kegiatan pendidikan, pelayanan kesehatan, penanaman nilai, dan pengembangan hubungan sosial dengan keluarga dan masyarakat sekitar. Kedua, untuk tujuan penyembuhan, pemberian bantuan, rehabilitasi, dan perlindungan sosial. Tujuannya ialah meningkatkan fungsi-fungsi yang tidak ada atau mengalami gangguan dengan memberdayakan masyarakat.

Ketiga, untuk membantu menjangkau dan menggunakan pelayanan yang sudah ada, pemberian informasi dan nasihat. Usaha untuk mempermudah akses dalam memanfaatkan pelayanan yang ada perlu dikembangkan 
kondisinya, serta kemampuan organisasiorganisasi soial masyarakat baik secara kuantitatif maupun kualitatif. Dan terakhir, untuk mendorong partisipasi pelayanan ini ditujukan untuk mendorong partisipasi dari golongan-golongan masyarakat yang selama ini tidak dilibatkan dalam pengambilan keputusan terutama golongan miskin atau termarjinalkan. Penyelenggaraan usaha-usaha kesejahteraan sosial pada hakekatnya tidak dapat dilakukan pemerintah sendiri, tetapi diperlukan keikutsertaan seluruh lapisan masyarakat. Pelayanan ini dimaksudkan untuk memulihkan atau meningkatkan kemampuan pelaksanaan peranan-peranan sosial perorangan, sehingga perlu peningkatan partisipasi masyarakat untuk memecahkan permasalahan kesejahteraan sosial. anggapan yang melandasi pelayanan ini adalah kekuatankekuatan lingkungan, keluarga, dan masyarakat.
Daftar pustaka

Dep. Sos. RI. (2008). Pedoman Umum Pelayanan Sosial Waria. Jakarta; Departemen Sosial.

Padmiaty, Etty. (2010). Waria: Antara Ada dan Tiada. Bandung; Bandung Press.

Fatma, Mia. 2011. Studi Fenomenologi; Pengalaman Waria Masa Remaja dalam Menangani Masalah Puber di Wilayah DKI Jakarta. Tesis Pada Ilmu Keperawatan Universitas Indonesia, Depok; tidak diterbitkan.

Rokhmah, Dewi dan Tri, Yenike. 2010. “Gaya Hidup Seksual Waria Non Pekerja Seks Komersial di Kota Semarang”. Jurnal Ilmu Kesehatan Masyarakat Universitas Jember.

Dep. Kes. RI. (2007). Surveilans Terpadu Biologi Perilaku di Indonesia. Jakarta. 